\title{
Research on Chinese and English Color Words under Cross-cultural Background
}

\author{
Li Wan \\ Zaozhuang University \\ Zaozhuang, China
}

\begin{abstract}
In human's language, there are many color words, which are frequently used in communication, thus they are endowed with rich emotional coloring and cultural connotation. There are abundant color terms in English and Chinese language. However, due to different cultural background and history of China and English speaking countries, the same color word has different symbolic meanings. This paper researches different symbolic meanings of several color words and analyzes differences between Chinese and western culture to promote cross-cultural communication.
\end{abstract}

Keywords-color words; symbolic meaning; cross-cultural communication

\section{INTRODUCTION}

With globalized development of world politics and economy, cross-cultural communication among various countries becomes more and more frequent and closer and closer. As a world language, English plays a vital role in crosscultural communication. Therefore, it is extremely important to master some cross-cultural communication knowledge between Chinese nation and English speaking nations in the current diversified culture and society.

Different nations' language can reflect the nation's national characters, history and culture, and it is influenced and limited by its own nation's society and culture at the same time. Color word is widely used in Chinese and English with extremely rich emotional coloring and cultural connotation. Apart from representing concrete colors, color words have different connotations due to differences in cultural background, religious belief and aesthetic psychology of China and western countries. Therefore, there is huge disparity in symbolic meaning of color words in China and western countries. This paper intends to compare and discuss the symbolic meaning of color words in Chinese culture and western culture.

\section{CONNOTATION OF VARIOUS COLOR WORDS IN CHINESE AND WESTERN CULTURE}

\section{A. White}

In Chinese traditional culture, "white" is a taboo term, foreboding evil and death. "White affairs", namely funeral rites, will be held for the death of a person. People usually set up a mourning hall and make white paper wreathes. People attending the funeral need to wear white mourning apparel. In
Chinese traditional culture, white also has a reactionary meaning. For example, the anti-revolution regime appearing at the end of the Qing dynasty is called "White regime". In addition, during the liberation war, the anti-revolution coup launched by reactionaries of the Nationalist Party is called "White terror". In the war, the army launching unjust acts is called "White army" and the defeated part usually waves a "white flag" representing surrender. In ancient times, "white coat" refers to plain folk, "white house" refers to banda and "white body" refers to people without official rank or scholarly honor. White can also refer to futile effort and unworthiness. For example, "vain thoughts", "vain effort", "vain action", etc.

In western culture, white symbolizes purity and happiness. Western wedding takes white as the dominant hue with the bride wearing a white wedding dress and relatives wearing white formal dresses. In the bible, angles are white and spotless In western fairy tale, snow white is the embodiment of purity and kindness. In addition, in western culture, white refers to peace, happiness, kindness, legitimacy and justice. For example, "a white lie", "a white spirit", "white market", "white man" and White House, the symbol of state power.

\section{B. Red}

No matter it is in the ancient times or nowadays, Chinese people see red as the embodiment of auspiciousness and joy. In many traditional festivals of China, red decorations are used, especially the Chinese New Year festivities of each year. Every household pastes red couplets, hangs red lanterns and makes red paper-cuts for window decoration. Even the firecrackers are mostly made by red paper. Besides, the elder give "red packets" to the younger generation, which is also called lucky money. In a wedding, red antithetical couplets are hung on walls and the bride wears red bridal makeup with red bridal veil on her head, foreboding happy and joyful marriage life. If new babies arrive at one family, the family will give relatives eggs painted in red, commonly known as "red lucky eggs", indicating joy and auspiciousness. Red also has the meaning of driving away and counteracting evil force. Many people wear red articles to pray for peace and good luck. In ancient times, red also symbolizes wealth and rank. The residence of high officials and noble lords is called "red-lacquered doors", the clothes they wear are called "red garments" and the carriage the carriage they sit in is called "red sedan". Besides, red is a color word with strong political color, signifying revolution and progress. For example, there is red army, red political power and red heart. 
In the western countries, a red vice dragon is mentioned in the revelation of the bible, saying that this red vice dragon can bring great disasters and red tragedies to human in the future (namely refers to now). It is bloodthirsty. Therefore, red is usually used as a derogatory term, symbolizing violence and blood. For example, there is be in the red, red tape, a red flag, red revenge, red army, see/turn red, and red-light strict. Of course, in western countries, sometimes red can refer to something good, for example, there is red carpet and red-letter day.

\section{Yellow}

Yellow skin, yellow land and the Yellow River water show Chinese people deep feeling about yellow color. As the legend goes, Chinese people's ancestor is Yellow Emperor. In ancient times, yellow is the symbol of power and wealth. The emperor wears a yellow dragon robe, imperial edict issued by the emperor is called "yellow edict" and residence of ancient emperor, like the Imperial Palace, has a yellow roof. Yellow also symbolizes wealth, like "golden yellow time" and "golden yellow week". Yellow can also refer to moral principles. For example, "yellow flower miss" refers to a chaste women and "yellow flower in one's later years" refers to scholars sticking to morality integrity in their later years. Yellow can also refer to good luck. For example, there is "yellow lucky day". "Yellow" can refer to young and immature, like "yellow hair girl". Of course, yellow also has derogatory meanings in Chinese, like "yellow leaves", "tomorrow's yellow flower" and "yellow dream". To describe a unhealthy person, you can say "emaciation with yellow complexion". Yellow can also refer to pornographic and degraded, like yellow novel, yellow movie and yellow jokes etc.

In English, apart from referring to yellow color, yellow is usually used in its derogatory sense. It can remind people of Judas who wears yellow clothes and betrays Jesus in the bible. Therefore, yellow has the meaning of betrayal and evil. In English, yellow can also refer to weak and timid, like yellow dog, yellow bellied, and yellow streak. Besides, yellow can refer to the color of a certain thing, like Yellow Pages, the yellow press, and Yellow Book. In America, taxis are yellow. Therefore, the sign on the taxi is yellow rather than taxi.

\section{Black}

In traditional Chinese culture, white and black symbolize bad luck, evil and disasters. For example, we call insidious and vicious people "black heart", some ugly hidden inside stories "black deal" and members of reactionary organization "black gang". Black can also refer to illegal criminal activity. For example, banditry is called "adopting the black path", taverns doing illegal dealings are called "black inn" and money obtained through corruption, bribery and other illegal means is called "black money". Besides, hell in the legend is called "netherworld", which is complete darkness. Therefore, black can symbolize darkness, terror and death. In Chinese, black can be both derogatory and commendatory. For example, in folk legend, the poker-faced "black faced" Bao Zheng symbolizes uprightness and justice. In addition, black represents solemnity in traditional Chinese culture. Official costume of ancient scholar-bureaucrats is black.
In western culture, black has multiple meanings. In westerners' heart, black is an evil color, symbolizing death and evil. "Black color" is called "death color" in the bible. For example, there is "a black day" and "black words". In western funerals, relatives and friends wear black clothes to show lament. Black can also symbolize shame and disgrace. For example, there is a black eye and black sheep. Black can also refer to gloomy mood, like I am in black mood. Similar to China, in western countries, black also symbolizes solemnity. Politicians, officials and well-known persons wear black clothes. Nearly all judges in court and performers of symphony orchestra wear black formal gowns. In economy English, black can refer to obtaining profit, like on the black and be in black ink.

\section{CONCLUSION}

Through the above analysis on cultural connotation of white, red, yellow and black in Chinese and English language, we find that color words have different cultural deposits and symbolic meanings in different languages. In Chinese culture, due to the influence of traditional thoughts and feudal rule, symbolic meaning of color word tends to be political and mysterious. On the contrary, symbolic meaning of color word in western culture is more scientific and rational. Therefore, we need to fully understand and research a nation's customs, values, humanity history and cultural tradition to grasp cultural message carried by and symbolic meaning of different color words in different languages and cultures. Only by doing so, can we conduct cross-cultural communications effectively and smoothly, thus contributing to integration of and communication between different languages and cultures.

\section{REFERENCES}

[1] Shi Bing. Contrastive Analysis on Cultural Connotation of Chinese Metaphor[J]. Liaoning Project Technology University Journal(Social Science Edition), (3) 20-21, 2003.

[2] Tang Yeyao. Contrastive Research on Cultural Connotation of Yellow in Chinese and English[J]. Changchun University of Science and Technology Journal, (2) 73-74, 2010.

[3] Yuan Yifei, Ji Mingping. Analysis on Social and Cultural Meaning of Color Words in English[J]. Zhengzhou University Journal, (3) 11-12, 1997.

[4] Zhang Jinsong. Culture-bound Words and Management of Them in Bilingual Dictionaries[J]. Jimei University Journal, (4) : 83- 87, 2001. 